\title{
INFLUENCE OF THE INTERFACE CONDITIONS ON FLEXIBLE PAVEMENT STRUCTURES LIFE
}

Ştefan Marian Lazăr, Lecturer PhD.eng., Technical University of Civil Engineering Bucharest, Department of Roads, Railways and Construction Materials, e-mail: lazar@cfdp.utcb.ro

Elena Diaconu, Prof.PhD.eng., Technical University of Civil Engineering Bucharest, Department of Roads, Railways and Construction Materials, e-mail: ediaconu@cfdp.utcb.ro

\section{Abstract}

This paper aims to establish the interface conditions influence on the flexible pavement structures life. The methodology consists in using the interface constitutive model available in the Alizé calculation program to calculate the stresses and strains in the flexible pavement structures.

The design criteria related to limiting fatigue cracking of asphalt layers and permanent deformations at the subgrade level from the road bed are used to estimate the flexible pavement structures lifetime.

When calculating the critical stresses and strains, most mechanical design methods of the flexible pavement structures considers that the road layers at interfaces are perfect bonded or total unbonded.

Proper modeling of the interface binding condition is an important aspect in understanding the real behaviour of in-service flexible pavement structures.

Keywords: interface conditions, flexible pavement structure, life

\section{Résumé}

Ce document vise à établir l'influence des conditions de l'interface sur la vie des structures routières souples. La méthodologie consiste à utiliser le modèle constitutif d'interface disponibles dans le programme de calcul Alizé pour calculer les contraintes et déformations dans les structures routières souples.

Pour estimer la durée de vie des structures routières souples, critères de dimensionnement sont utilisés pour limiter la fissuration par fatigue des couches d'asphalte et des déformations permanentes au niveau du sol du lit de la route.

Dans le calcul des contraintes et déformations spécifiques critiques, la plupart des méthodes mécaniques de la conception de structures routières souples estime que les couches de la route au niveau des interfaces sont parfaites liées ou totale non liée. 
La modélisation correcte de la condition de liaison de l'interface est un aspect important dans la compréhension du comportement réel des structures routières souples en fonctionnement.

Mots-clés: conditions d'interface, structure routière souple, durée de vie

\section{INTRODUCTION}

Ensuring the binding between pavement layers at the construction time is an essential condition to guarantee the performance of an in-service pavement structure. Many specialists in the road construction field have drawn attention to the fact that failure to ensure the binding at the interface between layers have adverse consequences for the pavement structures life [1,2 and 3].

Thus, one of the fundamental elements of pavement structures design is understanding how the interface conditions influences the pavement structures performance.

This paper aims to study the effects of the interface conditions on the lifetime of flexible pavement structures by computer modeling. Computer modeling is not as realistic as field work to real scale, but is much less expensive and can give quick answers to complex questions.

In Romania, in the current practice of flexible pavement structures design is used the CALDEROM 2000 computer program, which is part of the "Normative for flexible and semi-rigid pavement structures design" [4]. This computer program cannot impose as a working hypothesis than the binding to the layers interfaces, as must actually be built the pavement structure in situ.

For this reason in this paper it will be used for the numerical simulation the ALIZÉ computer program [5]. This computer program, developed by LCPC (Laboratoire Central des Ponts et Chaussées = Central Laboratory of Bridges and Roads) in the years 65, is the reference program used in the "French pavement structures design method" (LCPC, 1994) [6] and can simulate interface situations either with binding or no binding.

Starting with July 1992, a version of the ALIZÉ program was made available to the Roads Laboratory within the Faculty of Railways, Roads and Bridges of the Technical University of Civil Engineering Bucharest, by LCPC France, to serve teaching and research activities.

Both computer programs, CALDEROM 2000 and ALIZÉ, are based on analytical solving of the stress and strain state of the pavement structure under load, by using the Burmister multilayered elastic model [7]. 
Working mode consists of using the interface constitutive model available in the ALIZÉ computer program to calculate stresses and strains in flexible pavement structure chosen for study. To estimate the lifetime of the flexible pavement structure are used the design criteria for limiting fatigue cracking of the asphalt layers and permanent deformations at the subgrade level from the road bed.

\section{INTERFACE CONDITIONS MODELING}

All mechanical design methods of flexible pavement structures are based on calculation algorithms of stresses, strains and displacements in any point of the layered structure. To make easier the pavement structure modeling and calculation process, the most methods assume that the layers are perfectly bonded to each other. Only a few models allow the interface conditions modeling by a coefficient of binding at the interface with values between 0 (no binding) and 1 (with binding). Even so, choosing the value of the binding coefficient is difficult because there is no standard procedure for its determining [1].

ALIZÉ calculation program can simulate both types of interfaces, therefore was used in this paper to establish the pavement structure response expressed by the stress and strain state.

Pavement structure is modeled by elastic, linear, isotropic and homogeneous layers, infinite in plane, of finite thickness, except the semiinfinite subgrade, and loads caused by tires are treated as circular static loads, exerted as vertical efforts (vehicle weight).

The multilayer elastic system is thus subjected to a circular loading with uniform vertical pressure, representing the weight of standard semi-axle with twin wheels, transmitted on a circular area equivalent to the tire-road contact surface.

Characteristics of standard axle load of $115 \mathrm{kN}$ are the following:

- load on twin wheels: $\quad 57.5 \mathrm{kN}$;

- contact pressure: $\quad 0.625 \mathrm{MPa}$;

- contact surface radius: $17.1 \mathrm{~cm}$.

The calculation of stresses and strains is carried out in a limited number of points in the pavement structure, called observation points. These points correspond to points with maximum values of stresses and strains, defining for the pavement structure design, and to characteristic points of deflection from the road surface. 
The theoretical calculation of a pavement structure consists of comparing between the stresses and strains produced in structure by the traffic, and allowable stresses and strains of each material that makes up the pavement structure.

Below are presented the characteristics of flexible pavement structure chosen for the study (Table 1) and calculation assumptions relating to the interface conditions (Table 2).

Table 1. Geometric and material characteristics

\begin{tabular}{|c|c|c|c|}
\hline $\begin{array}{c}\text { Material in pavement } \\
\text { structure layer }\end{array}$ & $\begin{array}{c}\text { Layer } \\
\text { thickness, } \\
\text { h, cm }\end{array}$ & $\begin{array}{c}\text { Dynamic elastic } \\
\text { modulus, } \\
\text { E, MPa }\end{array}$ & $\begin{array}{c}\text { Poisson's ratio, } \\
\boldsymbol{\mu}\end{array}$ \\
\hline Asphalt concrete, BA 16 & 4 & 3600 & 0.35 \\
\hline Bituminous mixture, AB 25 & 6 & 5000 & 0.35 \\
\hline Ballast & 30 & 260 & 0.27 \\
\hline Subgrade, P1 & $\infty$ & 100 & 0.27 \\
\hline
\end{tabular}

Table 2. Interface conditions

\begin{tabular}{|c|c|c|c|}
\hline \multirow{2}{*}{ Case } & \multicolumn{3}{|c|}{ The interface between the layers of } \\
\cline { 2 - 4 } & wearing - base & base - subbase & subbase - subgrade \\
\hline A & 1 & 1 & 1 \\
\hline B & 0 & 1 & 1 \\
\hline C & 0 & 0 & 1 \\
\hline D & 0 & 0 & 0 \\
\hline E & 1 & 1 & 0 \\
\hline F & 1 & 0 & 0 \\
\hline G & 1 & 0 & 1 \\
\hline H & 0 & 1 & 0 \\
\hline
\end{tabular}

where $1=$ bonded interface,

$0=$ unbonded interface.

\section{FLEXIBLE PAVEMENT STRUCTURES LIFE}

To establish the performance of in-service pavement structure were used the two design criteria considered in the calculation of flexible pavement structures:

- admissible horizontal tensile strain at the basis of asphalt layers;

- admissible vertical compressive strain at the road bed level. 
In both cases, the allowable traffic values, appealing to the degradation laws specific to the bituminous materials and to the subgrade from the road bed (Fodor, 2009 [8]), were calculated as follows:

- the fatigue law for the bituminous mixture from the asphalt layers:

$N_{\text {adm }}=4,27 \times 10^{8} \times \varepsilon_{r}^{-3,97} \quad$ m.s.a. (million standard axles)

for highways, expressways, European roads, roads and streets with calculation traffic greater than $1 \mathrm{~m} . \mathrm{s} . \mathrm{a}$. of $115 \mathrm{kN}$;

$$
N_{\text {adm }}=24,50 \times 10^{8} \times \varepsilon_{r}^{-3,97} \text { m.s.a. }
$$

for roads and streets with calculation traffic at most equal to 1 m.s.a. of $115 \mathrm{kN}$;

- the permanent deformations law for the subgrade:

$$
N_{\text {adm }}=2,10 \times 10^{9} \times \varepsilon_{z}^{-3,70} \quad \text { m.s.a. }
$$

for highways, expressways, European roads, roads and streets with calculation traffic greater than $1 \mathrm{~m} . \mathrm{s} . \mathrm{a}$. of $115 \mathrm{kN}$;

$$
N_{\text {adm }}=8,36 \times 10^{9} \times \varepsilon_{z}^{-3,57} \text { m.s.a. }
$$

for roads and streets with calculation traffic at most equal to $1 \mathrm{~m}$.s.a. of $115 \mathrm{kN}$.

Further it has been established the pavement structure lifetime $(D V)$ in the calculation assumptions adopted using the following calculus equation [9] derived from Miner's Rule (1945) [10] of cumulative damage:

$$
D V=\frac{N_{\text {adm }}}{N_{c, \text { anual }}} \quad \text { years }
$$

in which: $N_{a d m}$ - the number of admissible loads, expressed in million standard axles of $115 \mathrm{kN}$, which can be supported by the designed pavement structure, according to the design criteria;

$N_{c, \text { anual }}$ - the calculation annual average traffic, expressed in million standard axles of $115 \mathrm{kN}$, determined by dividing the calculation traffic $\left(N_{c}\right)$ to the number of years corresponding to the perspective period of $\left(p_{p}\right)$ taken into account.

The lifetime calculation was made assuming that the calculation traffic is $\mathrm{N}_{\mathrm{c}}=1$ m.s.a. corresponding to a Traffic Class T2 - Heavy, according to CD 155-2001, and the perspective period is $p_{p}=10$ years.

\section{THE STUDY RESULTS}

Further, the study results are presented in the form of centralizing tables:

- the strain state in Table 3;

- the pavement structure lifetime in Table 4. 
ROMANIAN JOURNAL

OF TRANSPORT INFRASTRUCTURE

Ştefan Marian Lazăr, Elena Diaconu

Influence of the interface conditions on flexible pavement structures life

The three cases (A, E and $\mathrm{H}$ ) (Table 4) with long life have in common the binding between the base course and the subbase course (case H). At this aspect if it is added also binding to the top of the pavement structure, that is, between the wearing course and the base course results additional performance (case E). It results to be the ideal case where binding may be provided in addition also to the bottom of the pavement structure, that is, at the interface between the subbase course and the subgrade (case A).

The most dangerous case for the performance of an in-service pavement structure is to lose the binding between all layers of the pavement structure (wearing - base - subbase) (case C).

Table 3. The strain state at critical points of the pavement structure

\begin{tabular}{|c|c|c|}
\hline Case & $\begin{array}{c}\text { Horizontal tensile strain at the } \\
\text { basis of bituminous layers, } \boldsymbol{\varepsilon}_{\mathbf{r}}, \\
\text { microdef. }\end{array}$ & $\begin{array}{c}\text { Vertical compressive strain at } \\
\text { the road bed level, } \boldsymbol{\varepsilon}_{\mathbf{z}}, \\
\text { microdef. }\end{array}$ \\
\hline A & -249.1 & 692.3 \\
\hline B & -265.0 & 905.4 \\
\hline C & -410.9 & 1262.7 \\
\hline D & -441.0 & 738.3 \\
\hline E & -267.8 & 376.4 \\
\hline F & -383.5 & 567.5 \\
\hline G & -356.4 & 961.9 \\
\hline H & -283.1 & 492.1 \\
\hline
\end{tabular}

Table 4. Lifetime for $\mathbf{N}_{\mathrm{c}}=1$ m.s.a.

\begin{tabular}{|c|c|c|c|}
\hline \multirow[b]{2}{*}{ Case } & \multicolumn{2}{|c|}{ Lifetime on design criteria, in years } & \multirow[b]{2}{*}{$\begin{array}{c}\text { Lifetime, } \\
\text { DV, } \\
\text { years }\end{array}$} \\
\hline & $\begin{array}{c}\text { The criterion of } \\
\text { horizontal tensile strain } \\
\text { at the basis of bituminous } \\
\text { layers, } \varepsilon_{\mathrm{r}} \text {, microdef. }\end{array}$ & $\begin{array}{c}\text { The criterion of } \\
\text { vertical compressive } \\
\text { strain at the road bed } \\
\text { level, } \varepsilon_{\mathrm{z}}, \text { microdef. }\end{array}$ & \\
\hline A & 7.51 & 6.06 & 6.06 \\
\hline B & 5.87 & 2.32 & 2.32 \\
\hline $\mathrm{C}$ & 1.03 & 0.71 & 0.71 \\
\hline $\mathrm{D}$ & 0.78 & 4.82 & 0.78 \\
\hline $\mathrm{E}$ & 5.63 & 53.35 & 5.63 \\
\hline $\mathrm{F}$ & 1.35 & 12.32 & 1.35 \\
\hline G & 1.81 & 1.87 & 1.81 \\
\hline
\end{tabular}




\begin{tabular}{l|l|l|l}
$\mathrm{H}$ & 4.52 & 20.49 & 4.52 \\
\hline
\end{tabular}

In Figure 1 is presented graphically the flexible pavement structure life obtained in the calculation assumptions related to the possible interface conditions between pavement layers.

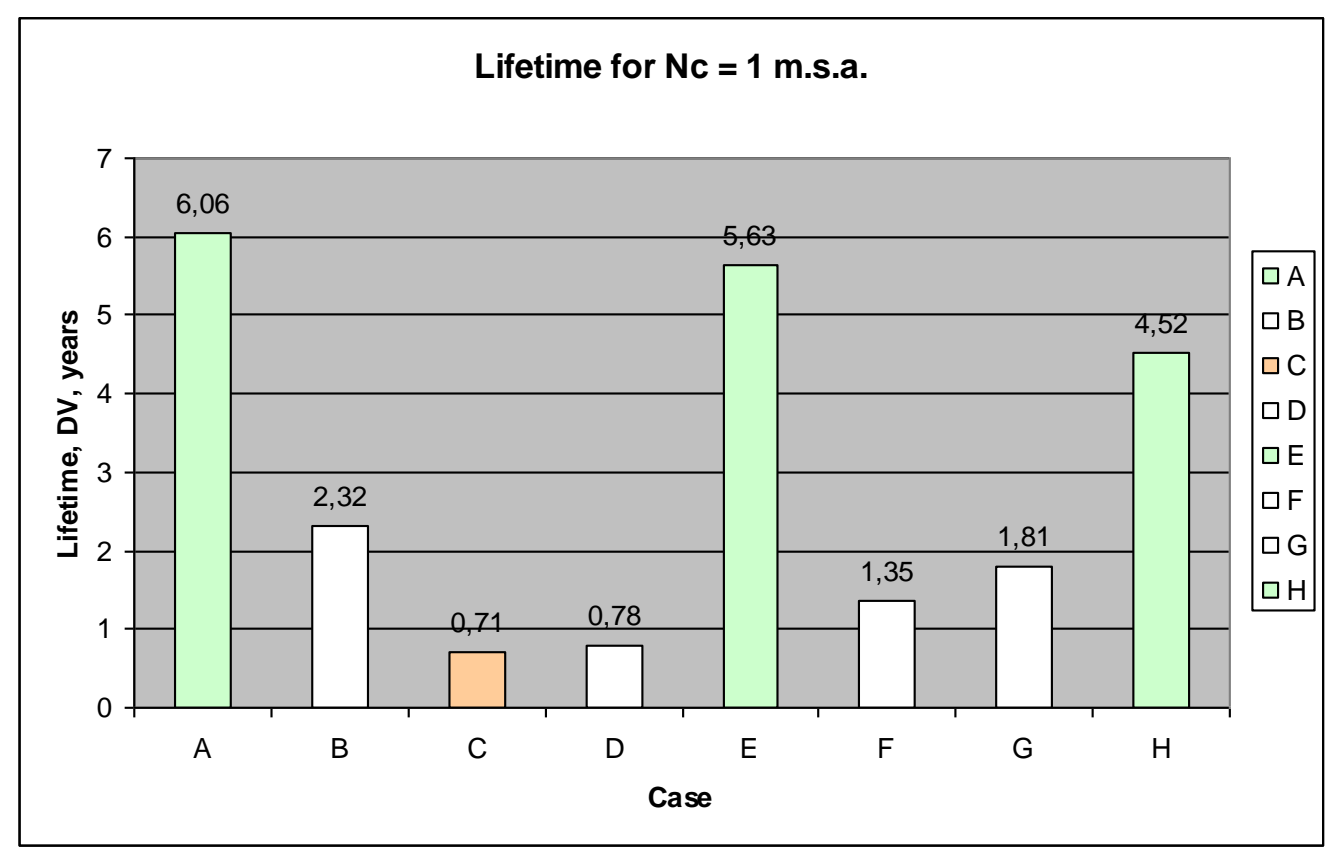

Figure 1. Flexible pavement structure life depending on the interface conditions

\section{CONCLUSIONS}

Proper modeling of the interface binding condition is an important aspect in understanding the real behaviour of in-service flexible pavement structures.

The most dangerous case for the performance of an in-service pavement structure is to lose the binding between all layers of the pavement structure (wearing - base - subbase).

The ideal case is the one that ensures binding to all the pavement layers interfaces including to the contact with the subgrade.

Thus, the paper highlights that providing of the binding between pavement layers at the construction time is an essential precondition to ensuring the performance of an in-service flexible pavement structure.

The study results by immediate practical implications are particularly useful for professionals from the flexible pavement structures design and construction field. 


\section{ROMANIAN JOURNAL \\ OF TRANSPORT INFRASTRUCTURE}

Ştefan Marian Lazăr, Elena Diaconu

Influence of the interface conditions on flexible pavement structures life

\section{REFERENCES}

[1]. H. ZIARI, M.M. KHABIRI, "Interface Condition Influence on Prediction of Flexible Pavement Life", Journal of Civil Engineering and Management, Vol. XIII, No. 1, pp. 71-76, 2007.

[2]. C. CĂPITANU, G. FODOR, S. CIOCA and C. DAMIAN, "Lack of adhesion between the bituminous layers, cause of premature structural deterioration of roads", Scientific Symposium "Technical state investigation and remediation procedures used for roads", TUCEB, Bucharest, June 28, 2002.

[3]. C. CĂPITANU, S. CIOCA and C. DAMIAN, "Analysis of some aspects of design calculations with negative consequences on the pavement structures performance", Scientific Symposium "Road Research and Administration", "CAR 2012", Edition $\mathrm{V}^{\text {th }}$, TUCEB, Bucharest, July 5, 2012.

[4]. ***, Normative for flexible and semi-rigid pavement structures design. (Analytical Method), ind. PD 177-2001.

[5]. ***, LCPC - Laboratoire Central des Ponts et Chaussées, "Alizé, Logiciel de calcul des contraintes et déformations dans un milieu multicouches élastique linéaire applique aux structures de chaussées”, Hugues Odéon, novembre 1991.

[6]. ***, LCPC, "Conception et dimensionnement des structures de chaussées”, Guide Technique, LCPC-SETRA, France, 1994.

[7]. D.M. BURMISTER, "The theory of the stress and displacements in layered systems and applications of design of airport runway, Proceeding of the Highway Research Board, 23, pp. 126-148, 1943.

[8]. G. FODOR and N. POPESCU, "Flexible and semi-rigid pavement structures. Design and composition”, Technical Guide, Revised Edition $2^{\text {nd }}$, BOMACO SRL, 2009.

[9]. C. DAMIAN, "Interpretation of results from flexible pavement structures measurement with Dynatest FWD equipment", Dissertation, Technical University of Civil Engineering Bucharest, 2009.

[10]. M.A. MINER, "Cumulative Damage in Fatigue”, Journal of Applied Mechanics, ASME, Vol. 12, Sept. 1945. 